SJ Quinney College of Law, University of Utah Utah Law Digital Commons

Utah Law Faculty Scholarship

Utah Law Scholarship

$12-2017$

\title{
Development of the Personal Genomics Industry
}

Jorge L. Contreras

S.J. Quinney College of Law, University of Utah, jorge.contreras@law.utah.edu

Vikrant Deshmukh

Follow this and additional works at: https://dc.law.utah.edu/scholarship

Part of the Health and Medical Administration Commons, and the Medical Genetics Commons

\section{Recommended Citation}

Development of the Personal Genomics Industry, in Genetics, Ethics and Education (Susan Bourgey et al., eds., Cambridge Univ. Press, 2017)

This Article is brought to you for free and open access by the Utah Law Scholarship at Utah Law Digital Commons. It has been accepted for inclusion in Utah Law Faculty Scholarship by an authorized administrator of Utah Law Digital Commons. For more information, please contact valeri.craigle@law.utah.edu. 
GENETICS, ETHICS AND EDUCATION

(Susan Bouregy, et al, eds., Cambridge Univ. Press: 2017)

\section{Chapter 13: Development of the Personal Genomics Industry}

By Jorge L. Contreras, J.D. and Vikrant G. Deshmukh, Ph.D., J.D.

Today, numerous commercial services offer genetic testing, genotyping and genome sequencing services both to medical providers and directly to the public.

Twenty-five years ago, such offerings would have been unthinkable, both in terms of cost and medical practice. This chapter describes the development of the personal genomics industry and its evolving business models and goals.

\section{Introduction}

A recent study found that, between the beginning of the Human Genome Project in 1990 and 2004, 470 different private firms in 25 countries began to offer products and services based on genomic technology or data (Wiechers, Perin, \& Cook-Deegan, 2013). These commercial offerings included the sale of genome sequencing equipment and reagents, the development of drugs and vaccines using genomic data (pharmacogenomics), testing for disease susceptibility, and a host of data-driven applications (Wiechers et al., 2013). Researchers at the Battelle Memorial Institute have estimated (Battelle, 2013) that by 2012, more than 47,000 individuals in the U.S. alone were employed by the genomics industry, which they divide into six primary sectors (bioinformatics, testing, reagents, instrumentation, R\&D and pharmacogenomics). Thus, although the commercial genomics industry has existed for only twenty-five years, it is large and complex, with widely varying product offerings, business models and strategies.

In this chapter, we focus only on those segments of the commercial genomics industry that offer products and services to end user consumers, either directly or through intermediaries such as physicians, genetic counselors or testing laboratories, a sector that we collectively refer to as "personal genomics" (Khoury et al., 2009). Our focus will further be limited to those products and services that provide genetic or genomic information to consumers, as opposed to drugs, vaccines or treatment regimens that may have been discovered using genomic information, or the administration of which may be influenced by a recipient's genomic characteristics. But even limited thus, the field is complex and multifaceted.

\section{Genetics and Genomics}

Each strand of human DNA consists of approximately 3.2 billion paired nucleotide bases, the sum of which is referred to as the human "genome." Some fraction of these bases is organized into contiguous sub-units called "genes," ranging in size from 
as few as a hundred to more than two million base pairs. It is currently estimated that human DNA contains approximately 20,000 genes. Genes are responsible for the inheritance of traits from one generation to the next and encode the many proteins responsible for biochemical functions within the cell. Each human genome is approximately $99.9 \%$ identical, and very small differences account for much of the variability in human physical and physiological traits (Feuk, 2006; NHGRI, 2014a), along with epigenetic variation (Issa, 2002).

While hypotheses regarding the existence of biochemical mechanisms for the heredity of human traits have existed since the nineteenth century, it was not until Watson and Crick's landmark discovery of the structure of DNA in 1953 that modern genetics was born. Throughout the 1960s and 1970s genetic studies became increasingly sophisticated, until by the mid-1970s, technology had evolved to a point at which researchers could begin to identify individual genes responsible for diseases such as Cystic Fibrosis and Huntington's disease (MacDonald, 1993; Rommens, 1989). Even so, each of these discoveries took years of painstaking work and a measure of good luck to achieve. In 1983 a revolutionary new process for determining the order of bases within a DNA molecule emerged. This process, called the Polymerase Chain Reaction (PCR), enabled researchers to unravel the genetic code of humans and many other organisms more efficiently (Mullis, 1987), and earned its inventor, Kary Mullis at Cetus Corporation, the Nobel Prize.

The advent of PCR technology soon gave rise to an ambitious plan to sequence not only genes identified with specific diseases, but the entire human genome (Watson \& Jordan, 1989). The decision by the U.S. government to form an international consortium to undertake this monumental project in the late 1980s signaled the birth of the field now known as genomics, the study not of individual genes, but of the entire genome.

\section{The Human Genome Project and Data-Driven Business Models}

For most of the twentieth century, the bulk of genetic research was carried out at academic institutions and government laboratories. The scale, sophistication and speculative nature of such research generally made it unattractive to commercial enterprises well into the first decade of the twenty-first century. The Human Genome Project (HGP) was officially launched in 1990 as a joint project of the U.S. National Institutes of Health (NIH) and the U.S. Department of Energy (DOE), with support from the Wellcome Trust in the United Kingdom and funding agencies in the United Kingdom, France, Germany and Japan.

The initial stages of the HGP were devoted to refining the instrumentation needed to sequence the human genome and undertaking pilot sequencing projects on simpler organisms such as the E. coli bacterium (Durham, 1997). By 1998, after the expenditure of nearly $\$ 2$ billion, the HGP prepared to begin work on the human genome. Then, in May of that year, J. Craig Venter, a former NIH scientist, famously proclaimed that he, with substantial commercial backing, would utilize state-of-the-art equipment, together with much of the HGP's publicly-released data, to sequence the entire human genome in only three years, a full four years before the HGP was scheduled to complete its work (Wade, 2000). Venter's announcement sent a shock wave through the genomics 
community and led to a widely publicized "arms race" between his new company, Celera Genomics, and the HGP (Roberts, 2001).

Ultimately, a truce was brokered by the journal Science (Jasny, 2013) and, in June 2000, Francis Collins, the leader of the HGP and Venter were invited to the White House to announce jointly that a "first draft" of the human genome had been completed (Wade, 2000). In his remarks, President Clinton emphasized the role of commercial enterprises in the new field of genomics, declaring that "[w]e must discover the function of these genes and their protein products, and then we must rapidly convert that knowledge into treatments that can lengthen and enrich lives. I want to emphasize that biotechnology companies are absolutely essential in this endeavor" (Clinton, 2000).

Unlike the public HGP, Celera's goal in sequencing the human genome was not to release genomic data to the public, but to profit from licensing this data to pharmaceutical and biotechnology companies. Like many companies, Celera sought to facilitate the emerging pharmacogenomics industry, which, it was hoped, would develop new and more effective drugs and vaccines guided by genomic information. Thus, while the public HGP regularly uploaded its DNA sequence data to the public GenBank database maintained by the U.S. National Library of Medicine, Celera made its data available solely on its commercial web site. The company allowed scientists from non-profit and academic institutions to access the data without charge, but required researchers who wished to use the data for commercial purposes to enter into a license agreement (Marshall, 2000).

Celera's approach outraged much of the scientific community and led to a highly publicized debate over private ownership of human genome data (Marshall, 2000). When Celera and the HGP announced the completion of their first drafts of the human genome in 2000, Celera committed that it would make its data broadly available, though it still required payment by commercial users (Marshall, 2001b). Celera's subscription-based data business was ultimately unsuccessful and, in 2005, the company exited the business and released its genomic data to GenBank (Kaiser, 2005). It is likely that Celera's datadriven business failed, in large part, due to the competing public efforts that released large quantities of similar, if not identical, data to the public.

In the 1990s Celera was just one of several firms that attempted to capitalize on potentially profitable uses of genomic sequence data. Even before the completion of the human genome project, firms including Incyte Pharmaceuticals in Palo Alto, California, and Human Genome Sciences in Rockville, Maryland, were actively pursuing a business strategy of patenting, and seeking to license, short gene sequences known as expressed sequence tags (ESTs) and other genetic data (Marshall, 2001a). By the time the first EST patent was issued to Incyte in 1998, that company alone had filed patent applications claiming more than 1.2 million DNA sequence fragments (Murry, 1999). These early efforts were eventually thwarted by a combination of factors including judicial and administrative decisions limiting the patentability of ESTs (Demaine, 2002), as well as earlier efforts to place large quantities of similar EST data into the public domain. The most notable of these earlier efforts was the "Merck Gene Index," a project led by pharmaceutical giant Merck in collaboration with Lawrence Livermore National Laboratory and Washington University (Contreras, 2011). By 1998, the Merck Gene Index had released over 800,000 ESTs through GenBank, substantially limiting the 
ability of companies to license the same or similar data to the pharmaceutical industry in a profitable manner.

A similar effort known as the SNP Consortium was conducted in conjunction with the HGP by a group of pharmaceutical and information technology companies, with additional support from the Wellcome Trust. The SNP Consortium sponsored research to identify and map genetic markers referred to as "single nucleotide polymorphisms" (SNPs), which it then released to the public domain (Holden, 2002; Contreras 2011). SNPs are common genetic variations that occur throughout a person's DNA, some of which are important in the study of human health (Genetics Home Reference, 2014a). The SNP consortium ultimately mapped 1.4 million SNPs, all of which were free from patents and made publicly accessible without charge.

It is likely that public data release efforts by the HGP and associated private sector projects such as the Merck Gene Index and the SNP Consortium limited the market for general purpose genomic databases, though, as we discuss below, there may still be substantial value in mutation databases associated with particular diseases.

\section{The Genetic Testing Sector}

The business models discussed in the section above were based on the private generation or collection of large quantities of genomic data, with the goal that this data then be licensed on a commercial basis to pharmaceutical and biotechnology companies engaged in pharmacogenomics research. A different business model developed from more narrowly-focused efforts to identify genetic mutations associated with particular diseases. As of this writing, more than 37,000 different genetic tests are available from 1,600 laboratories and clinics in the U.S. for nearly 4,000 genetic disorders (GeneTests, 2014). The vast majority of these genetic tests are available to patients only through a physician or clinical setting.

The first disease-specific genetic test was developed for Cystic Fibrosis, a debilitating condition that affects approximately 30,000 children and adults in the United States, and 70,000 worldwide (Cystic Fibrosis, 2014). A mutation in the CFTR gene that is strongly correlated with Cystic Fibrosis was discovered in 1989 by teams at the University of Michigan, Johns Hopkins University and the Hospital for Sick Children in Montreal. The discovery was patented, but each of the institutions holding patent rights elected to license its rights on a non-exclusive basis (meaning that the patent holder permitted multiple laboratories to perform testing, rather than only a single laboratory) (Chandrasekharan, Heaney, James, Conover, \& Cook-Deegan, 2010). As a result, in 2009 sixty-three different labs in the United States performed testing for CFTR mutations at relatively affordable prices (ibid.).

A different market structure developed with respect to tests in which controlling patents were licensed on an exclusive basis. For example, Athena Diagnostics of Marlborough, Massachusetts has exclusive rights to exploit patents covering genetic diagnostic tests for mutations of several genes associated with hearing loss and Alzheimer's disease. In the case of the $A P O E$ gene, whose particular variants are associated with late-onset Alzheimer's disease, Athena holds an exclusive license from 
Duke University and has actively sought to prevent other laboratories from offering testing based on this mutation (Skeehan, Heaney, \& Cook-Deegan, 2010). One exception arose in 2008, when Athena licensed a small company called Smart Genetics to offer $A P O E$ testing directly to consumers via a mail-in kit in conjunction with telephone consultation. But Smart Genetics discontinued its APOE testing program after only a few months, apparently following the intervention of Duke University (Skeehan et al., 2010).

The best-known example of commercial genetic testing is probably that of Myriad Genetics. Strong correlations between mutations in the BRCA1/2 genes and breast/ovarian cancer in certain populations were identified in the early 1990 s by research groups at the University of Utah and the U.S. National Institutes of Environmental Health Sciences (NIEHS) and two corporations: Myriad and Oncormed, Inc.. Myriad eventually obtained control over the patents covering the most significant $B R C A$ mutations and elected not to license third parties to perform testing. As a result, by 2000 Myriad was the only U.S. laboratory performing full $B R C A$ testing, for which it charged approximately $\$ 3,000$. Controversy arose due to the cost of Myriad's test and the fact that many U.S. healthcare payors, including the federal Medicare system, declined to cover $B R C A$ testing costs in many cases. Myriad's assertion of exclusive rights in the $B R C A$ testing market led a coalition of patients, advocacy groups, physicians and clinics to mount a legal challenge against Myriad's patents in 2009. The case led to a landmark 2013 decision by the U.S. Supreme Court invalidating all of the challenged patent claims and establishing that DNA sequences occurring in the human body are not eligible for patent protection in the U.S. (Ass'n for Molecular Pathology v. Myriad Genetics, Inc., 2013).

Shortly after the Myriad ruling, a number of additional firms, including laboratory giants Ambry Genetics and Laboratory Corporation of America, entered the market for $B R C A$ testing by offering tests at significantly lower price points than Myriad (Ambry, 2013; LabCorp, 2013). At this writing, Myriad is engaged in litigation seeking to enforce a new set of patents against these and other firms.

The degree to which Myriad will impact patents held by Athena and other diagnostic testing companies, and its overall effect on the genetic testing industry in the U.S., is still unclear. Several commentators believe that single-gene patents of the type held by Myriad and others would, in any event, be of little use to exclude competitors from performing whole genome sequencing and other tests that involve more than the isolation of single genes (Rai \& Cook-Deegan, 2013).

Outside of the U.S., patents covering genetic testing appear to be on more solid footing. The Australian Supreme Court, for example, recently upheld a number of Myriad's patents covering BRCA mutations ("Cancer Voices Australia v Myriad Inc [2014] FCAFC," 2014). The crux of the dispute was whether isolated DNA including complementary DNA (cDNA) was patent eligible. In holding both varieties of DNA to be patentable, the Australian Court arrived at a different conclusion than the U.S.

Supreme Court, which had held that isolated DNA was not patent eligible because it was a product of nature. In Europe, Myriad's BRCA1 and $B R C A 2$ patents were challenged and substantially upheld by the European Patent Office (EPO). However, during successive proceedings, the claims were reduced in scope from the entire BRCAl gene sequence to individual mutations, cloning vectors and host cells, and methods for 
detecting mutations in BRCA2 (Matthijs, Huys, Van Overwalle, \& Stoppa-Lyonnet, 2013). The resulting claim scope in Europe is substantially narrower than in either the U.S. or Australia.

\section{Direct-to-Consumer (DTC) Genomics}

Following the completion of the Human Genome Project, rapid advances in gene sequencing technology coupled with a precipitous drop in the price of sequencing equipment, led to the emergence of a new market: direct-to-consumer (DTC) genomic testing. DTC genomics vendors offer services directly to the public, typically without the involvement of a healthcare provider. These services typically involve the consumer's submission of a DNA sample (usually a saliva swab) to a designated facility, and the vendor's performance of one of three types of analysis: genotyping, exome sequencing or whole genome sequencing (see Kornilov, this volume).

The process of scanning a genome for known genetic markers or SNPs is called genotyping. Genotyping is typically performed by comparing a sample of human DNA to known markers on a commercially available panel or "chip". Vendors such as Illumina currently offer genotyping panels that contain over one million known markers. The presence or absence of the tested markers can support inferences about the subject's risk for certain diseases, ancestry and physiological characteristics.

While genotyping can offer a substantial amount of information to consumers, even the largest million-marker chips contain only a tiny fraction (i.e. $0.03 \%$ ) of the 3.2 billion base pairs comprising the full human genome. Sequencing the entire genome of an individual (whole genome sequencing) is a much larger task. The HGP spent approximately $\$ 3.8$ billion over a decade to sequence the genomes of multiple individuals to develop a common genomic profile for human species. The cost of genome sequencing has dropped precipitously in the years since the completion of the HGP. For years, the "holy grail" of genome sequencing has been the $\$ 1,000$ genome: the ability to sequence an entire human genome for a cost of only $\$ 1000$ (Davies, 2010). The National Human Genome Research Institute (NHGRI) tracks costs associated with whole genome sequencing at centers that it funds, and most recently estimated that this cost had dropped to between the $\$ 4,000$ and $\$ 5,000$ (Wetterstrand, 2014). And in 2014, Illumina announced that it "broke the sound barrier" of human genomics by enabling the $\$ 1000$ genome with a new sequencing platform (Illumina, 2014). Nevertheless, it is likely that the $\$ 1000$ genome still remains a few years away for the average consumer.

Meanwhile, companies like Gene by Gene offer a middle-road between genotyping and whole genome sequencing in the form of exome sequencing, which involves sequencing only those protein-coding fragments of an individual's genome. These 19,000 or so protein-coding regions represent about $1 \%$ of the entire human genome ( $\mathrm{Ng}$ et al., 2009), but can support medically valuable incidental/secondary findings (Green et al., 2013). Thus, exome sequencing avoids the high cost of whole genome sequencing, while offering more information than genotyping. 
Genetic ancestry testing (GAT) or genetic genealogy relies on an examination of variations in DNA to infer where a person's ancestors may have originated (Genetics Home Reference, 2014b). GAT is based on the idea that closely related individuals, families or populations share more genetic variations with one another. GAT can complement traditional genealogical research by providing missing pieces of ancestry information, but cannot itself provide detailed information about specific ancestors.

One of the first organizations to offer GAT to the public was the Genographic Project, a collaboration between the National Geographic Society and IBM. The Genographic Project began to distribute genetic testing kits in 2005 for a \$99 charge (Davies, 2010). The Project gave its participants information regarding their likely ancestry, along with historical perspectives on the migration paths followed by ancient peoples (Wells, 2005). The kits are still offered for $\$ 99$, and at the time of this writing over 688,000 individuals from more than 140 countries have participated in this project.

A number of additional commercial GAT tests are offered for approximately $\$ 99$ by companies including 23andMe, Ancestry.com DNA and Family Tree DNA. (23andMe, 2014a; Ancestry, 2014; Family Tree DNA, 2014).

\section{Nutritional Genomics}

The field of nutritional genomics pertains to interactions between genes and the environment, particularly nutrients, chemicals, and other matter introduced into the body as part of dietary food consumption (Dudley, 2013). For example, Familial Hypercholesterolemia (FH), a condition characterized by severely elevated LDL cholesterol and increased risk of coronary artery disease, can be traced to mutations in the $A P O B, L D L R$ and $P C S K 9$ genes. Individuals who carry these mutations are managed medically by a combination of diet and lifestyle changes, along with pharmacotherapy (Youngblom, 2014).

Some companies have tried to capitalize on public interest in nutritional genomics through consumer testing products. For example, Evidence Based Nutrition (EBN) based in Chula Vista, California, offers customers a "DNA Nutrition Action Plan" that "makes nutritional and lifestyle recommendations based on an understanding of the individual's unique genetic profile" (Spicer, 2008). EBN primarily sells nutritional supplements.

Sciona, Inc., headquartered in Aurora, Colorado, offers the MyCellf test, which it claims to be "designed to provide dietary and lifestyle recommendations gleaned from individual genetic data" (Davies, 2010). Author Kevin Davies took the MyCellf test and reported that Sciona recommended that he get more exercise, cut back on alcohol and caffeine, and increase his daily intake of vegetables (ibid.). Predictably, claims such as these from nutrigenetic testing firms have been criticized for being too generic at best, and at times misleading (Kutz, 2006).

\section{DTC and Health Information}

While using genomic information to provide information about ancestry and nutrition has commercial potential, these applications pale in comparison to the detection 
of health-related information hidden within the genomes of consumers. Home-based genetic paternity testing, as well as genetic testing for specific health conditions, have been available for years. Only with the increasing accessibility of genotyping and genomic sequencing, however, have consumers had the opportunity to obtain large quantities of data regarding their genomic make-up and its potential health implications.

In 1998, deCODE genetics, a Reykjavík, Iceland based biopharmaceutical company, lobbied for and won exclusive rights to revamp Iceland's national health record system, which included records containing patient diagnoses, treatments, results, complications, etc., as well as biospecimens, genotypes and genealogical records for the entire nation (Chadwick, 1999). deCODE discovered several genes associated with diseases in humans, and offered lab tests for various disease genotypes, in collaboration with Hoffman-LaRoche, Merck, and others, although a majority of these tests were not marketed to consumers.

In 2007, deCODE launched a web-based DTC genomics service called deCODEme, which was the first commercial offering of its kind. For less than $\$ 1,000$, deCODE would analyze approximately 600,000 sites in a customer's DNA having a known influence on both common physical traits such as baldness, eye color and tonguerolling, as well as risk for certain diseases including diabetes and several cancers (Davies, 2010). DeCODE conceptualized its offering as an educational service rather than a medical diagnostic, explaining "[w]e are not providing people with a genetic test. We are only allowing them to compare their genomes to the genomes of those who in the literature have been described as having a risk of a disease. We encourage people not to make medical decisions on the basis of results of this, but we point people to the possibility of taking results of this to their doctors..." (Davies, 2010).

In 2006, David Agus, an oncologist, and Dietrich Stephan, a neuroscientist, founded Navigenics, Inc. Navigenics offered DTC tests for eighteen common illnesses including diabetes, heart disease, obesity and certain cancers (Davies, 2010; Hall, 2007). One of the distinguishing features of Navigenics's approach was its heavy emphasis on genetic counseling. Recognizing the complexity and sensitive nature of individual genomic information, Navigenics required a "telephone consult" with one of its genetic counselors before giving a customer full access to his or her DTC testing results. Customers could also download their raw genomic data after signing a waiver.

The best-known purveyor of DTC genomic testing today is probably 23andMe, a California-based company founded by Linda Avey, Paul Cusenza and Anne Wojcicki in 2006 (23andMe, 2014a). In November 2007, 23 andMe joined deCODE and Navigenics in offering the public DTC testing that included ancestry and health information (Hanahan, 2007). Wojciki, the spouse of Google co-founder Sergey Brin, explained, "23andMe is designed to provide our customers with scientifically accurate, high-quality information about their own genetic code in a format that is easy to understand and use." 23andMe's bold approach and knack for publicity quickly grabbed the public imagination, and Time Magazine named it the 2008 'Invention of the Year' (TIME Magazine, 2008). 23andMe has also attracted investment from other pharmaceutical and biotechnology companies since its founding, and recently announced a $\$ 60$ million deal with biotech giant Genentech. A significant aspect of this investment will give Genentech access to the 23andMe database containing genotypic records of over 800,000 
customers (Herper, 2015). In February 2015, the U.S. Food and Drug Administration (FDA) allowed 23andMe to market the first DTC genetic carrier test for Bloom syndrome (U.S. Food and Drug Administration, 2015), a rare genetic disorder characterized by short stature and increased predisposition to cancer.

Even independently of 23 andMe, Google's interest in the field of genomics is not to be underestimated. In February 2014, the Internet giant launched Google Genomics, a web-based application for importing, storing, searching, analyzing and sharing individual genomic data (Gruber, 2014). Harvard professor George Church predicts that Google's data mining software will open "huge new markets in wellness and precision medicine (ibid.)."

Alongside these purveyors of broad spectrum DTC genomic information are numerous smaller firms that offer genotyping for specific non-disease traits. Among these is Richmond, Virginia based American International Biotechnology, which offers a \$200 test kit that "provides athletes and parents of young sports competitors a wealth of information about their athletic strengths" (AIBioTech, 2011). Some in the scientific community have questioned the validity of the conclusions that can be drawn from such information, and have criticized the marketing approach taken by AIBioTech and others (Collier, 2012).

\section{Comparing DTC Offerings}

With at least three major DTC personal genomics options available to consumers by the late 2000s, it became important to clarify how these services differed from one another. Whereas 23andMe took a self-service approach in providing the consumer with large quantities of easy-to-use information, Navigenics and deCODE preferred that consumers interact with genetic counselors to interpret their results. And while 23 andMe offered more information on complex traits, deCODE offered greater contextual information for data relating to ancestry (Davies, 2010).

The similarities and differences among DTC genomics offerings also became the object of scientific study. One such study found over $99.6 \%$ concordance in the SNP genotypes provided by deCODE, 23 andMe and Navigenics (most likely because they all used the same commercial genotyping technology), but noted large variations in the analysis of risks reported by these companies (Imai, Kricka, \& Fortina, 2011). For example, one study found that the relative risks for rheumatoid arthritis that the companies reported ranged from 0.9 to 1.85 , i.e. from having a protective effect to having a deleterious effect (ibid.). Similar findings were observed in other studies, and the differences were attributed, among other things, to the methods used in characterizing the underlying populations (Kalf et al., 2014).

While academic studies have provided a scientific comparison of DTC services, members of the media have also reported their experiences with DTC testing (Dickinson, 2008). Journalist Boonsri Dickinson, for example, compared her DTC test results from all three companies and received surprisingly divergent results. Having both Asian and European ancestry, she discovered that the risk information provided by the test vendors varied widely depending on whether she identified herself as belonging to one ethnic 
group or the other. Such critiques have cast increasing doubt on the usefulness and informative value of many DTC genomic services.

\section{Whole Genome Sequencing for All?}

Around the time that deCODE, 23andMe, and Navigenics were marketing DTC genomic tests based on known markers, others, like Harvard professor George M. Church, ventured in a different direction. Church was one of the first individuals to have his entire genome sequenced and joined other notable figures such as James Watson in releasing his genomic data to the public. Church founded Knome Inc. in 2007 to offer whole genome sequencing services to the general public, "on the recognition that the rapidly falling price of whole genome sequencing would create substantial market need for whole genome interpretation technologies and services" (Knome, 2014). Today, that vision has largely been realized; indeed, when Knome first offered whole genome sequencing, it cost a hefty $\$ 350,000$, whereas more recent cost estimates are in the $\$ 6,000$ range (Eisenberg, 2013).

Other notable companies in the whole genome sequencing arena included Helicos Biosciences and Complete Genomics. Helicos was founded in 2003 by Stephen Quake from the California Institute of Technology, and Stanley Lapidus and Noubar Afeyan of Flagship Ventures. Helicos specialized in a novel technique known as Single Molecule Sequencing, which allowed the sequencing of a single DNA molecule without the need for PCR, and offered an advantage over second-generation sequencing techniques at the time (Thompson \& Milos, 2011).

Complete Genomics was founded by Clifford Reid and Radoje (Rade) Drmanac in 2006. In 2009 the company began to offer whole genome sequencing services not to consumers, but to pharmaceutical and biotechnology companies and academic medical centers at a cost of approximately $\$ 5,000$ per genome (Lauerman, 2009). While Knome and Complete Genomics continue to offer whole genome sequencing services as of this writing, Helicos filed for bankruptcy in 2012.

The potential of DTC whole genome sequencing is significant. What cost the HGP $\$ 3.8$ billion to produce over ten years could soon be available to every man, woman and child for less than $\$ 1,000$ through a mail-in kit. The greatest challenge of DTC whole genome sequencing is how to interpret the vast quantity of genomic data that will be delivered to consumers. Modern science has only scratched the surface of understanding the myriad functions of the 3.2 billion base pairs that constitute the human genome. It will likely be many years before scientific understanding catches up with the technical ability to generate whole genome sequence data.

\section{Market Shake-out for DTC Vendors}

The financial crisis of 2008 put an enormous strain on many industries, and several DTC genomics providers went out of business. In November 2009, two years after initially offering its DTC service, deCODE filed for bankruptcy. deCODE got a fresh start in 2012, when it was acquired by biotech giant Amgen (Amgen, 2012). It is not clear, however, whether Amgen will restart deCODE's DTC genomics service, or simply use the Icelandic company's genetic resources and database to support its existing 
drug discovery and development businesses. In 2012, Navigenics also ceased to offer DTC genomic services after being acquired by Life Technologies, a subsidiary of equipment manufacturer Thermo Fisher Scientific. Whereas both deCODE and Navigenics struggled, 23andMe has flourished, attracting over \$100 million in investment from the likes of Google, Johnson and Johnson, and Genentech, and major private investors such as Google co-founder Sergey Brin and Digital Sky Technologies cofounder Yuri Milner (CrunchBase, 2014).

\section{Governmental Scrutiny of DTC Testing}

In 2004, the American College of Medical Genetics issued a statement that "genetic testing should be provided to the public only through the services of an appropriately qualified health care professional," warning that "the self-ordering of genetic tests by patients over the telephone or Internet [could result in harms including] inappropriate test utilization, misinterpretation of test results, lack of necessary followup, and other adverse consequences" (ACMG, 2004). This perspective has shaped the policy debate over DTC genomic services in the United States, and has led to significant intervention by state legislatures and federal agencies over the DTC genomics industry.

In the United States, state governments are generally responsible for regulating consumer health and safety, as well as the practice of medicine and licensure of healthcare providers within their borders. Depending on the state, laws and regulations may either expressly permit genomic DTC testing, ban such services outright, impose partial regulations or remain silent on the issue (Dick, 2012; Berman, 2007). Illustrating this range of regulatory regimes, Virginia explicitly allows direct reporting of DTC genomic results to individuals, California and New York require physician authorization, and Colorado and Utah classify DTC genomic testing outside the practice of medicine and thus beyond state licensure regulation (Dick, 2012).

In 2008, both California and New York began to require medical licensing for DTC genomics vendors and sent cease and desist letters prohibiting further sales to consumers without medical oversight (Langreth, 2008; Magnus, Cho, \& Cook-Deegan, 2009; Pollack, 2008). The targeted DTC companies objected, arguing that patients had a right to receive their genetic information, that genetic testing is not diagnostic or medical in nature, and that patients deserved direct access to testing without a physician intermediary (Magnus et al., 2009). Nevertheless, most DTC companies eventually complied with state demands and stopped accepting DNA samples from New York and California (Pollack, 2008). 23andMe, however, took a creative approach, still shipping kits to consumers in New York, but requiring them to "affirm under penalty of law that the sample for the saliva kit has not been collected in or mailed from the state of New York" (23andMe, 2014b). On the other hand, in 2010, Navigenics became one of the first DTC genomics companies to obtain a New York Clinical Laboratory Permit (Sweeney, 2010).

The U.S. federal government has also shown an interest in the activities of DTC genomics vendors. In 2006 the U.S. Government Accountability Office (GAO) launched an investigation of the practices of several DTC companies, and concluded in a subsequent investigation that they provided "medically unproven disease predictions" (G. Kutz, 2010). GAO's investigation involved the purchase of DTC tests by a number of 
fictitious consumers. These test subjects received disease and risk predictions that varied across four DTC companies for the same DNA samples, and contradicted known family history and other traits in the DNA donors.

DTC genetic testing is subject to the jurisdiction of at least three separate Federal regulatory agencies: the Federal Trade Commission (FTC), the Centers for Medicare and Medicaid Services (CMS), and the Food and Drug Administration (FDA)(NHGRI, 2014b).

The FTC regulates consumer protection and polices false and misleading advertising under the Federal Trade Commission Act. There have been numerous critiques of consumer DTC genomics advertising, pointing to its potential distortion of DTC testings' risks and benefits, its limited educational value and its potential for disseminating misinformation to the public (Gollust, Hull and Wilfond, 2002). As a result, the FTC has scrutinized DTC genomics advertising and has issued a consumer advisory on its website about DTC genetic tests, alongside other cautionary articles about "miracle health claims" and "cancer treatment scams" (Federal Trade Commission, 2014).

CMS regulates clinical laboratory testing (excluding research) throughout the U.S. under the Clinical Laboratory Improvement Amendments (CLIA) of 1988, which covers the educational requirements, quality control and proficiency testing of individual labs. In order to offer medical tests to the public and return results to consumers, laboratories performing DTC genomic testing must have an appropriate CLIA certificate (CMS, 2014).

Separately from CMS's regulation of clinical laboratories, the FDA regulates medical devices marketed in the U.S. under the Medical Devices Amendments to the Federal Food, Drug and Cosmetic Act. FDA's broad oversight of medical devices has been argued to extend to laboratory-developed tests and test kits, as well as related software (Javitt \& Carner, 2014).

In 2009, the FDA, which had become increasingly concerned about the distribution of genomic diagnostic information by unregulated DTC vendors, began to seek more information regarding DTC practices and tests. The major DTC genomics vendors largely sidestepped the FDA's inquiries, and matters came to a head in the summer of 2010, when the FDA issued warning letters to several vendors including 23andMe, Navigenics, and deCODE (U.S. Food and Drug Administration, 2010). According to the FDA, the kits and services offered by these vendors fell under the Medical Devices Amendments, and these firms had neither filed for premarket approval, nor notified the agency of their intent to commercially distribute the respective devices. On this basis, the FDA ordered these companies to discontinue marketing DTC genomic services until they received marketing authorization from the FDA, and to provide documentation about specific corrective actions they had undertaken to address these issues (ibid.).

As a result of the FDA's actions, in December 2013, 23andMe announced that it was discontinuing the '23andMe Health' personal genomics service, which had provided consumers with health-related interpretive information along with the results of its genotyping analysis, pending an FDA regulatory review (Afarian, 2013). 23andMe 
switched instead to providing its customers with raw SNP data (i.e., the actual genotypic test results indicating the presence of particular SNPs at particular locations along the genome), along with ancestry information. Other DTC companies that offered similar tests followed suit, limiting their offerings to raw SNP data and leaving consumers to perform their own interpretations.

Despite the current unavailability of interpretive or health information from DTC vendors, consumers who obtain SNP and other raw genomic data about themselves are not without options. Free software tools such as Promethease (Promethease, 2014) can generate personal genomics reports using raw sequence data based on publicly available scientific literature in the public SNPedia (Cariaso \& Lennon, 2012; SNPedia, 2014). Promethease can import data directly from the reports offered by vendors such as 23 andMe, and can also decipher raw data files that most DTC vendors provide to consumers. The actual process involves matching raw SNP data with known SNPs in SNPedia, and using that knowledge base to generate meaningful interpretation. Other websites such as interpretome.com (Karczewski, 2012), livewello.com (Livewello, 2015), and geneticgenie.org (Genetic Genie, 2015) also offer "interpretation-only" services for DTC tests similar to Promethease. Due to the rapid pace of discovery and the relative newness of these services, there is no gold standard. Nevertheless, one recent study found Promethease results to be among the most detailed, although not as user-friendly as the services originally offered by 23 andMe (Regalado, 2014). Ultimately, the accuracy of these tools is only as good as the underlying data sources. SNPedia, for instance, has at least four levels of data curation, three of which are directly performed on the database itself, whereas an additional fourth level of review is dedicated to the content used by Promethease, and helps screen errors in original research in the original data-sources (Cariaso \& Lennon, 2012).

\section{Personal Genomics outside the U.S.}

Though, with the exception of deCODE in Iceland, the personal genomics initiatives of U.S. firms have received most of the attention from the Western press, such efforts are not limited to the U.S. market. Regulators around the world have weighed the benefits and risks of genetic testing, including DTC, for several years, and legal developments in Europe bear striking similarities to those in the United States. In 2008, following the approval of protocols related to genetic testing by the Committee of Ministers of the Council of Europe, some speculated that Europe might move toward banning DTC testing altogether (Borry, 2008). In 2009, Germany enacted legislation that effectively banned DTC genomic services by requiring that genetic tests be carried out exclusively by a physician following informed patient consent (The Associated Press, 2009). France, Portugal and Switzerland have similar legislation restricting DTC genomics, while the Netherlands only has limited restrictions on genetic tests for detecting "incurable diseases" (Borry et al., 2012). The United Kingdom and Belgium currently have no specific restrictions on DTC genomic testing (ibid.).

In the EU, DTC testing is currently covered by European Directive 98/79, which proposes objectives, but is not directly binding on member states, many of which have national legislation that covers these tests (Kalokairinou, 2014). However, a new proposed regulation, if adopted by the EU, would be binding on member states. The regulation proposes a risk-classification system for medical devices including DTC tests. 
It further provides that agencies must evaluate claims before such tests could be marketed (ibid). Finally, the regulation would also provide that only medical professionals can order these tests. Such a change in regulatory posture could effectively ban DTC in Europe (ibid.).

Like the U.S., China has seen the emergence of a significant personal genomics industry, offering consumers both genetic testing for common health risks (especially neonatal screens), as well as more comprehensive genomic data (Jia, 2014). It has been reported that many Chinese hospitals routinely offer genomic sequencing services to healthy patients during check-ups (ibid.) The increasing popularity of personal genomic services in China has led Chinese regulators to take notice, and it is likely that greater scrutiny and regulation of the personal genomics market in China will soon arrive.

Despite these moves toward greater regulation of DTC testing, there have also been calls for scaling back the initial precautionary approach taken by regulators in light of newer studies, which show that many of the public health concerns over DTC have not materialized (Vayena, 2013). In a recent study, most participants in multiplex genetic susceptibility testing recalled their results correctly, did not interpret results in an overly deterministic way, and appreciated that genetics and behavior both contribute to disease risk (Kaphingst, 2012). In another study, subjects who underwent DTC testing exhibited no measurable short-term changes in psychological health, diet and exercise behavior, or use of screening tests (Bloss, 2011).

While commercial genomics itself knows no boundaries, and consumers from different parts of the world could potentially send their DNA samples to vendors based in other countries, until regulatory frameworks around the world catch up with the technology, the industry may need to self-regulate in the consumers' interest (Gurwitz \& Bregman-Eschet, 2009). Whereas many laboratory-developed tests would arguably fall within the definition of a "device" that is subject to FDA regulation, there is a lack of data to support pre-market clearance, and the FDA cannot control off-label uses of these tests (McGuire, 2010). Moreover, many DTC tests provide predictive and long-term information, whereas post-market surveillance may provide a better long-term strategy as long all tests are analytically valid, and all clinical claims are accurate and substantiated (ibid.).

Additionally, typical DTC contracts include numerous legal disclaimers and limitations of liability (Phillips, 2015). Most consumers lack the training to interpret these terms, or do not invest the time to do so. While regulation may be necessary to protect consumer interests, in the short-term DTC companies can also improve the readability of their contracts and privacy policies to enhance consumer understanding and the consent process (ibid.). The lessons learned in early adopter countries like the United States and several European nations are pertinent to consumers and companies around the world due to their impact on the availability and demand for DTC and other forms of genetic testing.

\section{Conclusion}


Over the past twenty-five years, the increasing speed and decreasing cost of genotyping and genome sequencing have led to the emergence of new business models based on providing genetic information directly to the public. Genetic tests for individual diseases are widely available today in many developed countries at moderate cost, and are covered by many national and private insurance plans. DTC genomic testing offered by 23 andMe and similar providers has increased in popularity, but the medical value of these services remains to be proven. Such services also face increasing governmental scrutiny and regulation, either as healthcare providers or diagnostic device vendors, making their future uncertain. Whole genome sequencing, which will soon be broadly affordable, offers consumers a wealth of information, but much of the information that is delivered is not likely to be understood for years. As such, the value of whole genome sequencing, as opposed to genotyping for known disease risks, remains questionable.

The global market for personal genomic products and services is likely to evolve rapidly over the next five to ten years. DTC companies have responded to changes in the regulatory environment by emphasizing services like ancestry information to maintain their primary revenue streams. Other companies have begun to offer interpretation-only services for personal genomics, which have not yet received the same level of scrutiny as similar services previously offered by DTC companies. Finally, in addition to the primary market for these products, collaborations between DTC and major biotechnology and pharmaceutical companies could create secondary markets and augment their primary business models along the lines of 23 andMe. It is not clear which of today's players, if any, will remain active in the future, or whether new players will enter the market from other sectors such as computing, information technology and online services, and whether early U.S. players will remain dominant in the face of market entry by competitors in China and elsewhere. What is certain, however, is that the amount of genomic information available to the general public will continue to increase rapidly, and novel legal, ethical and economic solutions will need to keep pace with this remarkable technological growth.

\section{References}

23andMe, Inc. (2014a). 23andMe - Genetic kit for ancestry | DNA Service. Retrieved 09-21-2014, from https://www.23andme.com/

23andMe, Inc. (2014b). Availablility in the state of New York. Retrieved 10-17-2014, from https://customercare.23andme.com/hc/en-us/articles/202907950-Availablility-in-the-state-of-NewYork

American College of Medical Genetics (ACMG) Directors. (2004). ACMG Statement on Direct-toConsumer Genetic Testing. Genet Med, 6(1), 60-60.

Afarian, C. (2013). 23andMe, Inc. Provides Update on FDA Regulatory Review [Press release]. Retrieved 10 -09-2014, from http://mediacenter.23andme.com/blog/2013/12/05/23andme-inc-providesupdate-on-fda-regulatory-review/

Ambry Genetics. (2013). Ambry Genetics Launches BRCA 1 \& 2: Single Genes and NGS Panel Offerings [Press release]. Retrieved 10-09-2014, from http:/www.ambrygen.com/press-releases/ambrygenetics-launches-brca-1-2-single-genes-and-ngs-panel-offerings

Amgen. (2012). Amgen to Acquire deCODE Genetics, a Global Leader in Human Genetics [Press release]. Retrieved 10-09-2014, from http://www.amgen.com/media/media_pr_detail.jsp?releaseID=1765710

Ancestry. (2014). DNA Tests for Ethnicity \& Genealogical DNA testing at AncestryDNA. Retrieved 1007-2014, from https://dna.ancestry.com/ 
Ass'n for Molecular Pathology v. Myriad Genetics, Inc., 133 S.Ct. 2107 (2013).

Battelle, T. P. P. (2013). The Impact of Genomics on the U.S. Economy.

Berman Institute of Bioethics, G. P. P. C., Johns Hopkins University. (2007). Survey of Direct-toConsumer Testing Statutes and Regulations. Retrieved 10-14-2014, from http://www.dnapolicy.org/resources/DTCStateLawChart.pdf

Bloss, C. S., Schork, N. J., \& Topol, E. J. (2011). Effect of Direct-to-Consumer Genomewide Profiling to Assess Disease Risk. New England Journal of Medicine, 364(6), 524-534. doi: doi:10.1056/NEJMoa1011893

Borry, P. (2008). Europe to ban direct-to-consumer genetic tests? Nat Biotech, 26(7), 736-737.

Borry, P., van Hellemondt, R. E., Sprumont, D., Jales, C. F. D., Rial-Sebbag, E., Spranger, T. M., . . . Howard, H. (2012). Legislation on direct-to-consumer genetic testing in seven European countries. Eur J Hum Genet, 20(7), 715-721.

Cancer Voices Australia v Myriad Inc [2014] FCAFC, 115 (2014).

Cariaso, M., \& Lennon, G. (2012). SNPedia: a wiki supporting personal genome annotation, interpretation and analysis. Nucleic Acids Research, 40(Database issue), D1308-D1312. doi: 10.1093/nar/gkr798

Centers for Medicare \& Medicaid Services (CMS). (2014). Direct Access Testing (DAT) and the Clinical Laboratory Improvement Amendments (CLIA) Regulations. Retrieved 10-10-2014, from http://www.cms.gov/Regulations-andGuidance/Legislation/CLIA/Downloads/directaccesstesting.pdf

Chadwick, R. (1999). The Icelandic database-do modern times need modern sagas? (Vol. 319).

Chandrasekharan, S., Heaney, C., James, T., Conover, C., \& Cook-Deegan, R. (2010). Impact of gene patents and licensing practices on access to genetic testing for cystic fibrosis. Genet Med, 12(1s), S194-S211.

Clinton, B. (2000). Text of Remarks on the Completion of the First Survey of the Entire Human Genome Project. Retrieved 09-15-2014, from http://clinton5.nara.gov/WH/New/html/genome20000626.html

Collier, R. (2012). Genetic tests for athletic ability: Science or snake oil? Canadian Medical Association Journal, 184(1), E43-E44. doi: 10.1503/cmaj.109-4063

Contreras, J. L. (2011). Bermuda's Legacy: Policy, Patents and the Design of the Genome Commons. Minnesota Journal of Law, Science \& Technology, 12, 61.

CrunchBase. (2014). 23andMe - Investors. Retrieved 10-07-2014, from http://www.crunchbase.com/organization/23andme/investors

Cystic Fibrosis Foundation (2014). About CF: What is Cystic Fibrosis? Retrieved 10-12-2014, from http://www.cff.org/aboutcf/

Davies, K. (2010). The \$1,000 Genome: The Revolution in DNA Sequencing and the New Era of Personalized Medicine. New York: Simon and Schuster.

deCODE Genetics, Inc. (2007). deCODE Launches deCODEme ${ }^{\mathrm{TM}}$ [Press release]. Retrieved 10-09-2014, from http://www.decode.com/decode-launches-decodeme/

Demaine, L. J. F., Aaron Xavier. (2002). Reinventing the Double Helix: A Novel and Nonobvious Reconceptualization of the Biotechnology Patent. Stan. L. Rev., 55, 303.

Dick, H. C. (2012). Risk and Responsibility: State Regulation and Enforcement of the Direct-to-Consumer Genetic Testing Industry. St. Louis University Journal of Health Law \& Policy, 6(1).

Dickinson, B. (2008). How Much Can You Learn From a Home DNA Test? Discover Magazine. Retrieved 09-23-2014, from http://discovermagazine.com/2008/sep/20-how-much-can-you-learnfrom-a-home-dna-test

Dudley, J. T. K., Konrad J. (2013). Personal genomics and the environment Exploring Personal Genomics (Kindle ed., pp. Kindle location 4178). Oxford, UK: Oxford University Press.

Durham, S. (1997). E. Coli Genome Reported [Press release]. Retrieved 03-08-2015 from http://www.nih.gov/news/pr/sept97/nhgra-04.htm

Eisenberg, A. (2013). Genomic Analysis, the Office Edition. The New York Times. Retrieved 10-07-2014, from http://www.nytimes.com/2013/02/03/business/knomes-new-machine-to-aid-labs-in-genomicanalysis.html? $\mathrm{r}=0$

Family Tree DNA. (2014). Family Tree DNA. Retrieved 10-14-2014, from https://http://www.familytreedna.com/ 
Federal Trade Commission (2014). Direct-to-Consumer Genetic Tests. Health \& Fitness: Treatment \& Cures. Retrieved 10-17-2014, from http://www.consumer.ftc.gov/articles/0166-direct-consumergenetic-tests

Feuk, L., Carson, A. R., \& Scherer, S. W. (2006). Structural variation in the human genome. Nat Rev Genet, 7(2), 85-97. doi: http://www.nature.com/nrg/journal/v7/n2/suppinfo/nrg1767 S1.html

GeneTests. (2014, 09-15-2014). GeneTests. Retrieved 09-15-2014, from http:/www.genetests.org/

Genetic Genie | Methylation and Detox Analysis from 23andMe Results. (2015). Retrieved 03-22-2015, from http://geneticgenie.org/

Genetics Home Reference. (2014a, 10-09-2014). What are Single Nucleotide Polymorphisms (SNPs) Genetics Home Reference. Retrieved 10-17-2014, from http://ghr.nlm.nih.gov/handbook/genomicresearch/snp

Genetics Home Reference. (2014b, 10-09-2014). Genetic Testing Genetics Home Reference Handbook: Help Me Understand Genetics (pp. 143-145): Lister Hill National Center for Biomedical Communications, U.S. National Library of Medicine. Retrieved 10-17-2014, from http://ghr.nlm.nih.gov/handbook.pdf.

Gollust, S. E., Hull, S., \& Wilfond, B. S. (2002). LImitations of direct-to-consumer advertising for clinical genetic testing. JAMA, 288(14), 1762-1767. doi: 10.1001/jama.288.14.1762

Green, R. C., Berg, J. S., Grody, W. W., Kalia, S. S., Korf, B. R., Martin, C. L., . . Biesecker, L. G. (2013). ACMG recommendations for reporting of incidental findings in clinical exome and genome sequencing. Genet Med, 15(7), 565-574. doi: 10.1038/gim.2013.73

Gruber, K. (2014). Google for genomes. Nat Biotech, 32(6), 508-508. doi: 10.1038/nbt0614-508a

Gurwitz, D., \& Bregman-Eschet, Y. (2009). Personal genomics services: whose genomes[quest]. Eur J Hum Genet, 17(7), 883-889.

Hall, J. (2007). Navigenics Launches With Preeminent Team of Advisers, Partners and Investors [Press release]. Retrieved 10-09-2014, from

http://investor.affymetrix.com/phoenix.zhtml?c=116408\&p=irolnewsArticle\&ID $=1073452$ \&highlight $=$

Hanahan, E., \& Kranhold, P. (2007). 23andMe Launches Web-Based Service Empowering Individuals to Access and Understand Their Own Genetic Information [Press release]. Retrieved 10-09-2014, from http://mediacenter.23andme.com/press-releases/23andme-launches-web-based-serviceempowering-individuals-to-access-and-understand-their-own-genetic-information/

Herper, M. (2015, 01-06-2015). Surprise! With \$60 Million Genentech Deal, 23andMe Has A Business Plan - Forbes. Retrieved 03-23-2015, from

http://www.forbes.com/sites/matthewherper/2015/01/06/surprise-with-60-million-genentech-deal23andme-has-a-business-plan/

Holden, A., L. (2002). The SNP Consortium: Summary of a Private Consortium Effort to Develop an Applied Map of the Human Genome. BioTechniques, 32, 22 - 26.

Illumina. (2014). Illumina Introduces the HiSeq X ${ }^{\text {TM }}$ Ten Sequencing System [Press release]. Retrieved 1009-2014, from http://investor.illumina.com/phoenix.zhtml?c=121127\&p=irolnewsArticle\&ID=1890696\&highlight $=$

Imai, K., Kricka, L. J., \& Fortina, P. (2011). Concordance Study of 3 Direct-to-Consumer Genetic-Testing Services. Clinical Chemistry, 57(3), 518-521. doi: 10.1373/clinchem.2010.158220

Issa, J. P. (2002). Epigenetic variation and human disease. The Journal of Nutrition, 132(8), 2388S-2392S.

Jasny, B. (2013). Realities of data sharing using the genome wars as case study - an historical perspective and commentary. EPJ Data Science, 2(1), 1.

Javitt, G. H., \& Carner, K. S. (2014). Regulation of Next Generation Sequencing. The Journal of Law, Medicine \& Ethics, 42(s1), 9-21. doi: 10.1111/jlme.12159

Jia, H. (2014). China's watchdog clamps down on genome sequencing services. Nat Biotech, 32(6), 511 511. doi: 10.1038/nbt0614-511

Kaiser, J. (2005). Celera to End Subscriptions and Give Data to Public GenBank. Science, 308(5723), 775. doi: 10.1126/science.308.5723.775a

Kalf, R. R. J., Mihaescu, R., Kundu, S., de Knijff, P., Green, R. C., \& Janssens, A. C. J. W. (2014). Variations in predicted risks in personal genome testing for common complex diseases. Genet Med, 16(1), 85-91. doi: 10.1038/gim.2013.80

Kalokairinou, L., Howard, H. C., \& Borry, P. (2014). Changes on the horizon for consumer genomics in the EU. Science, 346(6207), 296-298. 
Kaphingst, K. A., McBride, C. M., Wade, C., Alford, S. H., Reid, R., Larson, E., . . Brody, L. C. (2012). Patients/' understanding of and responses to multiplex genetic susceptibility test results. Genet Med, 14(7), 681-687. doi: http://www.nature.com/gim/journal/v14/n7/suppinfo/gim201222s1.html

Khoury, M. J., McBride, C. M., Schully, S. D., Ioannidis, J. P. A., Feero, W. G., Janssens, A. C. J. W., . . . $\mathrm{Xu}$, J. (2009). The Scientific Foundation for Personal Genomics: Recommendations from a National Institutes of Health-Centers for Disease Control and Prevention Multidisciplinary Workshop. Genet Med, 11(8), 559-567.

Knome, Inc. (2014). About - Knome. Retrieved 09-23-2014, from http://www.knome.com/about/

Konrad J, K., Robert P, T., Pablo, C., Nicholas P, T., Joel T, D., Keyan, S., . . Stuart K, K. I. M. Interpretome: A Freely Available, Modular, and Secure Personal Genome Interpretation Engine. Biocomputing 2012 (pp. 339-350).

Kutz, G. (2010). Direct-To-Consumer Genetic Tests: Misleading Test Results Are Further Complicated by Deceptive Marketing and Other Questionable Practices. (GAO-10-847T). U.S. Government Accountability Office Retrieved 10-14-2014, from http://www.gao.gov/assets/130/125079.pdf

Kutz, G. D. (2006). Tests Purchased from Four Web Sites Mislead Consumers. (GAO-06-977T). Retrieved 10-14-2014, from http://www.gao.gov/products/GAO-06-977T

LabCorp, Inc. (2013). LabCorp to Offer BRCAssureSM Breast Cancer Mutation Tests [Press release]. Retrieved 10-14-2014, from http://phx.corporate-ir.net/phoenix.zhtml?c=84636\&p=irolnewsArticle \&ID $=1881008$

Langreth, R. H., Matthew. (2008). States Crack Down On Online Gene Tests. Forbes. Retrieved 10-082014, from http:/www.forbes.com/2008/04/17/genes-regulation-testing-bizcx mh bl 0418genes.html

Lauerman, J. (2009, 02-05-2009). Complete Genomics Drives Down Cost of Genome Sequence to $\$ 5,000$ Bloomberg. Retrieved 10-09-2014, from http://www.bloomberg.com/apps/news?pid=newsarchive\&sid=aEUlnq61tPpQ

Livewello. (2015). Retrieved 03-22-2015, from https://livewello.com/

MacDonald, M. E., Ambrose, C. M., Duyao, M. P., Myers, R. H., Lin, C., Srinidhi, L., .. . Harper, P. S. A novel gene containing a trinucleotide repeat that is expanded and unstable on Huntington's disease chromosomes. Cell, 72(6), 971-983. doi: 10.1016/0092-8674(93)90585-E

Magnus, D., Cho, M., \& Cook-Deegan, R. (2009). Direct-to-consumer genetic tests: beyond medical regulation? Genome Med, 1(2), 17.

Marshall, E. (2000). Storm Erupts Over Terms for Publishing Celera's Sequence. Science, 290(5499), 20422043. doi: 10.1126/science.290.5499.2042

Marshall, E. (2001a). Bermuda Rules: Community Spirit, With Teeth. Science, 291(5507), 1192. doi: 10.1126/science.291.5507.1192

Marshall, E. (2001b). Sharing the Glory, Not the Credit. Science, 291(5507), 1189-1193. doi: 10.1126/science.291.5507.1189

Matthijs, G., Huys, I., Van Overwalle, G., \& Stoppa-Lyonnet, D. (2013). The European BRCA patent oppositions and appeals: coloring inside the lines. Nat Biotech, 31(8), 704-710. doi: $10.1038 /$ nbt. 2644 http://www.nature.com/nbt/journal/v31/n8/abs/nbt.2644.html

McGuire, A. L., Evans, B. J., Caulfield, T., \& Burke, W. (2010). Regulating Direct-to-Consumer Personal Genome Testing. Science, 330(6001), 181-182.

Mullis, K. B., Erlich, H. A., Arnheim, N., Horn, G. T., Saiki, R. K., \& Scharf, S. J. (1987). One of the first Polymerase Chain Reaction (PCR) patents; US4683195.

Murry, J. (1999). Owning Genes: Disputes Involving DNA Sequence Patents. Chi.-Kent. L. Rev., 75, 231.

National Human Genome Research Institute (NHGRI) (2014, 02-14-2014). FAQ About Genetic and Genomic Science. Retrieved 03-22-2015, from http://www.genome.gov/19016904\#al-2

National Human Genome Research Institute (NHGRI) (2014, 09-02-2014). Regulation of Genetic Tests. Retrieved 10-13-2014, from http://www.genome.gov/10002335

Ng, S. B., Turner, E. H., Robertson, P. D., Flygare, S. D., Bigham, A. W., Lee, C., . . Shendure, J. (2009). Targeted capture and massively parallel sequencing of 12 human exomes. Nature, 461(7261), 272276. doi: http://www.nature.com/nature/journal/v461/n7261/suppinfo/nature08250_S1.html

Phillips, A. M. (2015). Think Before You Click: Ordering a Genetic Test Online. SciTech Lawyer, Winter 2015, 11(2). 
Pollack, A. (2008). Gene Testing Questioned by Regulators The New York Times. Retrieved 10-08-2014, from http://www.nytimes.com/2008/06/26/business/26gene.html

Promethease. (2014). Promethease. Retrieved 10-07-2014, from https://promethease.com

Rai, A. K., \& Cook-Deegan, R. (2013). Moving Beyond "Isolated” Gene Patents. Science, 341(6142), $137-$ 138. doi: $10.1126 /$ science. 1242217

Regalado, A. (2014). How a Wiki Is Keeping Direct-to-Consumer Genetics Alive. The Year in Review: Health Care. MIT Technology Review. Retrieved 03-22-2015, 2015, from http://www.technologyreview.com/featuredstory/531461/how-a-wiki-is-keeping-direct-toconsumer-genetics-alive/

Roberts, L. (2001). Controversial From the Start. Science, 291(5507), 1182-1188. doi: 10.1126/science.291.5507.1182a

Rommens, J. M., Iannuzzi, M. C., Kerem, B., Drumm, M. L., Melmer, G., Dean, M., . . al, e. (1989). Identification of the cystic fibrosis gene: chromosome walking and jumping. Science, 245(4922), 1059-1065. doi: 10.1126/science. 2772657

Skeehan, K., Heaney, C., \& Cook-Deegan, R. (2010). Impact of gene patents and licensing practices on access to genetic testing for Alzheimer disease. Genet Med, 12(1s), S71-S82.

SNPedia. (2014). SNPedia. Retrieved 10-07-2014, from http://www.snpedia.com/index.php

Spicer, D. (2008). Evidence Based Nutrition, Inc., First to Offer Sciona MyCellf ${ }^{\mathrm{TM}}$ DNA Personalized Genetics Analysis Kit to Chiropractors [Press release]. Retrieved 10-09-2014, from http://www.reuters.com/article/2008/02/19/idUS155080+19-Feb-2008+BW20080219

Sweeney, B. (2010). Navigenics Receives State of New York Clinical Laboratory Permit [Press release]. Retrieved 10-14-2014, from http://www.businesswire.com/news/home/20100112005741/en/Navigenics-Receives-State-YorkClinical-Laboratory-Permit

The Associated Press. (2009, 04-24-2009). Germany limits genetic testing. U-T San Diego. Retrieved 1009-2014, from http://www.utsandiego.com/news/2009/apr/24/eu-germany-genetic-testing-042409/

Thompson, J., \& Milos, P. (2011). The properties and applications of single-molecule DNA sequencing. Genome Biology, 12(2), 217.

TIME Magazine. (2008). 1- The Retail DNA Test - Best Inventions of 2008 - TIME. Retrieved 09-212014, from http://content.time.com/time/specials/packages/article/0,28804,1852747_1854493_1854113,00.ht $\mathrm{ml}$

U.S. Food and Drug Administration. (2010). In Vitro Diagnostics - FDA. Retrieved 09-24-2014, from http:/www.fda.gov/MedicalDevices/ProductsandMedicalProcedures/InVitroDiagnostics/default.ht $\underline{\mathrm{m}}$

U.S. Food and Drug Administration. (2015). FDA permits marketing of first direct-to-consumer genetic carrier test for Bloom syndrome [Press release]. Retrieved 03-09-2015, from http:/www.fda.gov/NewsEvents/Newsroom/PressAnnouncements/UCM435003

Vayena, E., \& Prainsack, B. (2013). The challenge of personal genomics in Germany. Nat Biotech, 31(1), 16-17.

Watson, J. D., \& Jordan, E. (1989). The human genome program at the National Institutes of Health. Genomics, 5(3), 654-656. doi: http://dx.doi.org/10.1016/0888-7543(89)90040-2

Wade, N. (2000, 06-27-2000). Genetic Code of Human Life Is Cracked by Scientists. The New York Times. Retrieved 10-06-2014, from http://partners.nytimes.com/library/national/science/062700scigenome.html

Wells, S. (2005). The Genographic Project. Retrieved 09-21-2014, from https://genographic.nationalgeographic.com/about/

Wetterstrand, K. A. (2014). DNA Sequencing Costs: Data from the NHGRI Genome Sequencing Program (GSP). Retrieved 10-07-2014, from http://www.genome.gov/sequencingcosts/

Wiechers, I., Perin, N., \& Cook-Deegan, R. (2013). The emergence of commercial genomics: analysis of the rise of a biotechnology subsector during the Human Genome Project, 1990 to 2004. Genome Medicine, 5(9), 83.

Youngblom E, K. J. (2014). Familial Hypercholesterolemia. In A. M. Pagon RA, Ardinger HH, et al. (Ed.), GeneReviews ${ }^{\circledR}$ [Internet]. Seattle, WA: University of Washington, Seattle. Retrieved 10-09-2014, from http://www.ncbi.nlm.nih.gov/books/NBK174884/ 